\title{
The Phase and Morphology of $\mathrm{Cu}_{2} \mathrm{ZnSnSe}_{4}$ Nanopowders by Hydrothermal Method
}

\author{
Kegao Liu, ${ }^{1}$ Nianjing Ji, ${ }^{2}$ Ludan Shi, ${ }^{1}$ and Hong Liu ${ }^{2}$ \\ ${ }^{1}$ School of Materials Science and Engineering, Shandong Jianzhu University, Fengming Road, Jinan 250101, China \\ ${ }^{2}$ State Key Laboratory of Crystal Materials, Shandong University, 27 Shandanan Road, Jinan 250100, China \\ Correspondence should be addressed to Kegao Liu; liukg163@163.com
}

Received 14 July 2014; Revised 8 September 2014; Accepted 15 September 2014; Published 13 October 2014

Academic Editor: Vladimir Sivakov

Copyright (c) 2014 Kegao Liu et al. This is an open access article distributed under the Creative Commons Attribution License, which permits unrestricted use, distribution, and reproduction in any medium, provided the original work is properly cited.

\begin{abstract}
Quaternary compound $\mathrm{Cu}_{2} \mathrm{ZnSnSe}_{4}$ (CTZSe) which belonged to $\mathrm{I}_{2}-\mathrm{II}-\mathrm{IV}-\mathrm{VI}_{4}$ group, without rare elements, can be considered as the perfect material for absorbing layer in eco-friendly solar cells due to low cost and high efficiency. The CTZSe powders were synthesized by hydrothermal coreduction method from metal chlorides and $\mathrm{SeO}_{2}$ with reducing agent hydrazine hydrate at $160 \sim 200^{\circ} \mathrm{C}$. The phases of obtained products were analyzed by X-ray diffraction (XRD) and the size and morphology were observed by field emission scanning electron microscope (FESEM). Experimental results show that well crystallized $\mathrm{Cu}_{2} \mathrm{ZnSnSe}_{4}$ powders without Se impurities can be obtained by reacting at $200^{\circ} \mathrm{C}$ for $90 \mathrm{~h}$. The three strong XRD peaks of these products are corresponding to (112), (204), and (312) crystal planes, respectively. The morphologies of these products mostly show irregular polygon flakes with about 30 40 nm thickness and 50 200 nm diameters.
\end{abstract}

\section{Introduction}

As the bellwether of the new generation of solar cells, the conversion efficiency of $\mathrm{Cu}(\mathrm{InGa}) \mathrm{Se}_{2}$ (CIGS) cell has been as high as $20.3 \%$ [1]. So a crucial position has been taken by the thin film solar cells of $\mathrm{CuInSe}_{2}$ (CIS) in the photovoltaic market. Since rare and costly elements such as In and Ga are contained in above compounds. The new cheap elements have been consistently researched for their alternatives. It greatly reduced the cost of raw materials by replacing In and Ga in CIGS with cheap $\mathrm{Zn}$ and $\mathrm{Sn}$ atoms in quaternary compound semiconductors $\mathrm{Cu}_{2} \mathrm{ZnSnS}_{4}$ (CZTS) or $\mathrm{Cu}_{2} \mathrm{ZnSnSe}_{4}$ (CZTSe).

As a p-semiconductor with optical band within $1.0 \mathrm{eV}$ $1.56 \mathrm{eV}$ and absorption coefficient $10^{4} \mathrm{~cm}^{-1}$ [2], CZTSe is the ideal absorber layer material in solar cells and becomes one research focus of photoelectric materials. A dramatic progress has been made in the efficiency of these solar cells. During the past three years, two conversion efficiencies of 9.6\%, $10.1 \%$ for the liquid processed CZTSe batteries have been reported by the Todorov group successively $[3,4]$.
The methods for preparing CZTSe thin film mainly include coevaporation [5], sputtering [6], and electrochemical deposition [7]. All of these techniques must be performed under restrictive fabrication conditions, such as vacuum or conductive substrates. In addition, solution based synthesis of CZTS nanoparticles and selenization in the layer after coating is a very common method to prepare CZTSe layers. $\mathrm{Cu}_{2} \mathrm{ZnSnSe}_{4}$ films have been fabricated by vacuum evaporation onto soda-lime glass substrates covered with molybdenum [8]. It indicated that nearly single-phase $\mathrm{Cu}_{2} \mathrm{ZnSnSe}_{4}$ films were deposited through the use of binary precursors and highly crystalline, P-type $\mathrm{Cu}_{2} \mathrm{ZnSnSe}_{4}$ films with an optical band gap of $1.14 \mathrm{eV}$ were produced via $\mathrm{SnSe}_{2}$ selenization. $\mathrm{Cu}_{2} \mathrm{ZnSnSe}_{4}$ thin film with large grains of 1$8 \mu \mathrm{m}$ was prepared through sputtering with a metallic $\mathrm{Cu}-$ $\mathrm{Zn}$-Sn target and a subsequent selenization procedure at 550 $650^{\circ} \mathrm{C}$ under the existence of $\mathrm{SnSe}_{2}$ and $\mathrm{CuSe}_{2}$ pellets [9]. This method requires the specific conditions of high vacuum and large equipment.

Wet chemical methods such as solvothermal method were mostly used in preparation of CZTSe powders. 


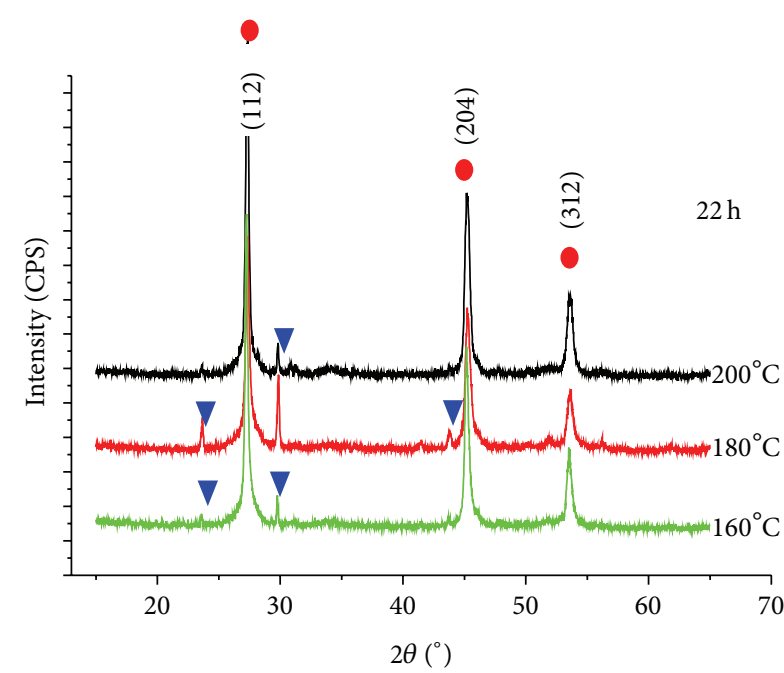

- $\mathrm{Cu}_{2} \mathrm{ZnSnSe}_{4}$ $\nabla \mathrm{Se}$

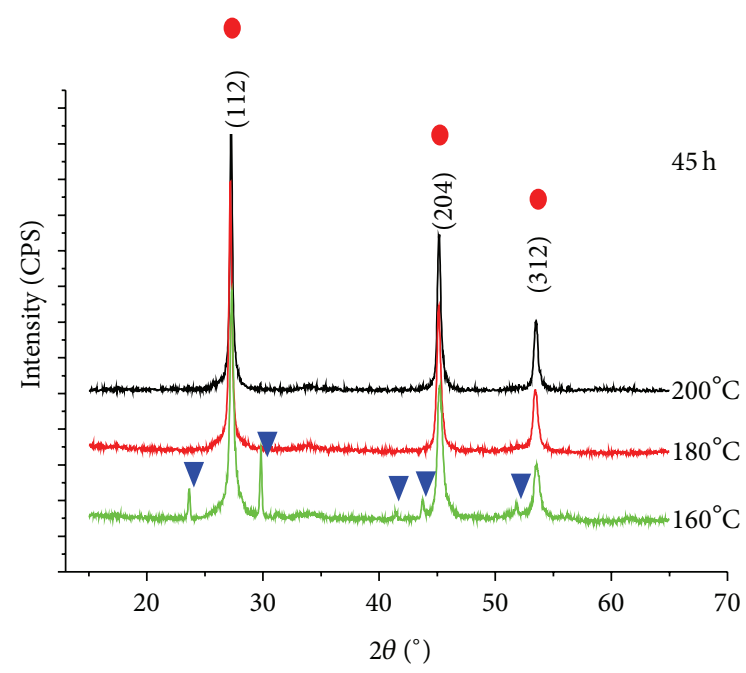

- $\mathrm{Cu}_{2} \mathrm{ZnSnSe}_{4}$

$\nabla \mathrm{Se}$

(a)

(b)

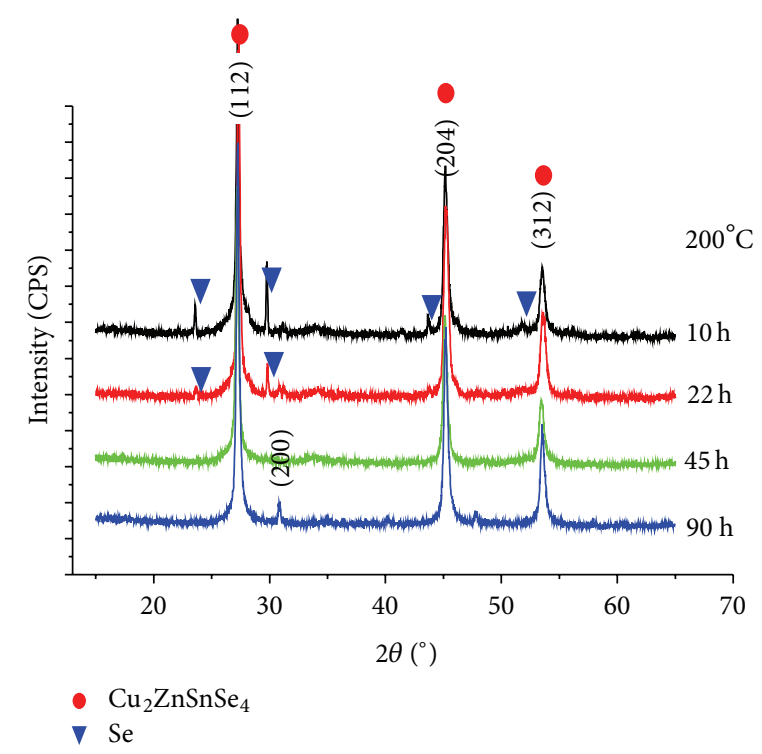

(c)

FIGURE 1: XRD patterns of the CZTSe powders prepared under different conditions.

Nanocrystalline CZTSe prepared by wet chemical method was first reported by Alexey Shavel group [10]. Nanocrystalline CZTSe was synthesized through the process of dissolving single-substance Se and metal salts, respectively, in a solution of triethanolamine and heating at $200^{\circ} \mathrm{C}$, where triethanolamine acts as reaction solvent, reducing agent, and complexing agent [11]. The CZTSe particles were synthesized in different solvents; the morphology of the particles is hexagon sheet-like when ethylene glycol was used as solvent; the sphere-like rough surface was observed with ethylenediamine as solvent [12]. The CZTSe nanoparticles with sizes of $7 \sim 35 \mathrm{~nm}$ were prepared through the process of dissolving corresponding metal salts in oleylamine at $170^{\circ} \mathrm{C}$ and heating for $30 \mathrm{~min}$, then pouring into oleylamine solution of single substance Se, and heating at $230^{\circ} \mathrm{C}$ for $90 \mathrm{~min}$ [2]. CZTSe nanoparticles were synthesized in an organic solution under nitrogen atmosphere at $235^{\circ} \mathrm{C}$ via thermal reaction of elemental $\mathrm{Cu}, \mathrm{Zn}, \mathrm{Sn}$, and Se powders in an IPDA chelated solution [13]. However, it is easy to produce a series of adverse reactions with this method whose reaction factors are not easy to be mastered. Previous studies have reported the synthesis of CZTSe nanocrystals via these methods; however, it still needs to develop a simple and practical synthesis route that expands the practicality of these 
materials in commercial products. This work provides a simple and easy-to-handle way to produce low-price and ecofriendly $\mathrm{Cu}_{2} \mathrm{ZnSnSe}_{4}$.

\section{Experimental Details}

For preparing CZTSe powder, $\mathrm{CuCl}_{2} \cdot 2 \mathrm{H}_{2} \mathrm{O}, \mathrm{ZnCl}_{2}$, $\mathrm{SnCl}_{2} \cdot 2 \mathrm{H}_{2} \mathrm{O}$, and $\mathrm{SeO}_{2}$ with a ratio of $2: 1: 1: 4$ were added into a stainless steel autoclave with a teflon liner of $20 \mathrm{~mL}$ capacity. The autoclave was filled with absolute ethyl alcohol and deionized water $(1: 2)$ up to $80 \%$ of the total volume. After ultrasonic agitation for about $30 \mathrm{~min}, 1 \mathrm{~mL}$ $\mathrm{HCl}$ and $2 \mathrm{~mL}$ hydrazine hydrate $\left(\mathrm{N}_{2} \mathrm{H}_{4} \cdot \mathrm{H}_{2} \mathrm{O}\right)$ were poured into the reactants. The autoclave was sealed and heated at different temperatures $\left(160^{\circ} \mathrm{C}, 180^{\circ} \mathrm{C}\right.$, and $\left.200^{\circ} \mathrm{C}\right)$ for $10 \sim 90 \mathrm{~h}$ in an electric furnace. After heating, it was cooled down to room temperature naturally. The black products were collected by filtration, washed with deionized water and absolute ethanol, and then dried at $70^{\circ} \mathrm{C}$.

The phases of product samples were analyzed by X-ray diffraction (XRD) on a model of Bruker D8 Advance XRD system with Nifiltered $\mathrm{Cu}-\mathrm{K} \alpha(\lambda=1.5059 \AA)$. The size and morphology of the products were observed using a model of Hitachi S-4800 field emission scanning electron microscope (FESEM). The compositions of $\mathrm{Cu}_{2} \mathrm{ZnSnSe}_{4}$ powder were analyzed by energy dispersive spectrometer (EDS) as the attachment of Hitachi S-4800 FESEM.

\section{Results and Discussion}

3.1. Synthesis of $\mathrm{Cu}_{2} \mathrm{ZnSnSe}_{4}$ by Hydrothermal Coreduction. Figure 1 shows XRD patterns of CZTSe nanometer powders synthesized under different conditions. According to the standard pdf card of $\mathrm{Cu}_{2} \mathrm{ZnSnSe}_{4}$ (No. 52-0868), it indicates that the major phase $\mathrm{Cu}_{2} \mathrm{ZnSnSe}_{4}$ can be synthesized in the products obtained at 160,180 , and $200^{\circ} \mathrm{C}$ as shown in Figure 1. The diffraction peaks at the $2 \theta$ angles of $27.1^{\circ}$, $45.1^{\circ}$, and $53.4^{\circ}$ were corresponding to (112), (204), and (312) crystal planes, respectively. These results are in good agreement with those Liu et al. [11] and Weia et al. [14] reported. From Figure 1(a) it can be seen that Se impurity was produced at each temperature with the same reaction time $22 \mathrm{~h}$. Figure 1(b) shows that impurity Se was only produced at lower temperature $160^{\circ} \mathrm{C}$ with reaction time $45 \mathrm{~h}$. It can be clearly seen, at $200^{\circ} \mathrm{C}$ with different reaction time, Se impurity was produced at $10 \mathrm{~h}$ and $22 \mathrm{~h}$ in Figure 1(c). An $\mathrm{X}$-ray diffraction peak corresponding to (200) crystal plane appeared at $2 \theta=31.1^{\circ}$ of samples with reaction time $90 \mathrm{~h}$. Therefore, well-crystallinity $\mathrm{Cu}_{2} \mathrm{ZnSnSe}_{4}$ nanopowder can be produced under the conditions of higher temperature and longer time.

3.2. Discussion about Identification of $\mathrm{Cu}_{2} \mathrm{ZnSnSe}_{4}$ Phase. For distinguishing the CZTSe phase from other three phases of $\mathrm{Cu}_{2} \mathrm{SnSe}_{4}, \mathrm{ZnSe}$, and $\mathrm{Cu}_{2} \mathrm{Se}$, Figure 2 shows the standard pdf cards of CZTSe, $\mathrm{Cu}_{2} \mathrm{SnSe}_{4}, \mathrm{ZnSe}$, and $\mathrm{Cu}_{2} \mathrm{Se}$. According to Figure 2, Figure 1(c) indicates that the product powder is not $\mathrm{Cu}_{2} \mathrm{SnSe}_{4}$ phase because the XRD peak at (200) crystal plane

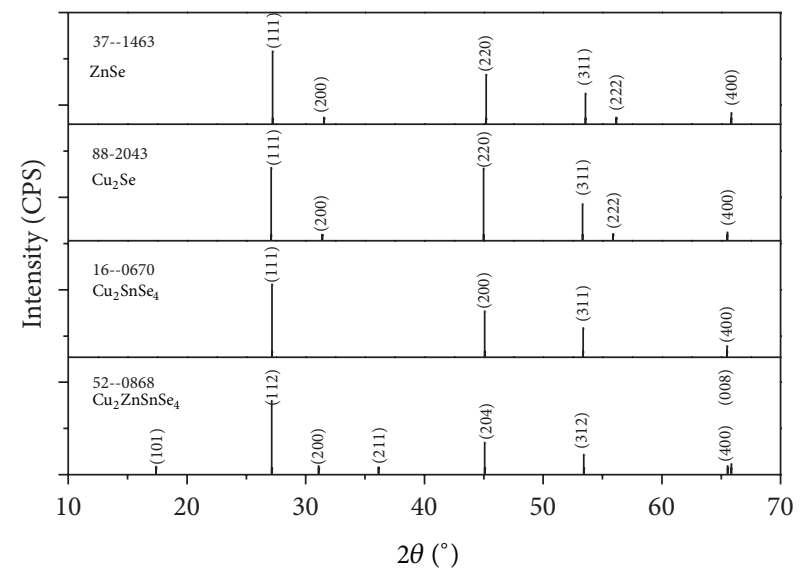

FIgure 2: Standard XRD pdf cards of CZTSe, $\mathrm{Cu}_{2} \mathrm{SnSe}_{4}, \mathrm{ZnSe}$, and $\mathrm{Cu}_{2} \mathrm{Se}$.

of the product powder prepared at $200^{\circ} \mathrm{C}$ for $90 \mathrm{~h}$ appeared. Authors have prepared $\mathrm{Cu}_{2} \mathrm{Se}$ [15] and $\mathrm{ZnSe}$ powders using the same method. ZnSe powder is yellow, so it is easily to be distinguished from black CZTSe powder. Therefore, it is the most difficult to distinguish between $\mathrm{Cu}_{2} \mathrm{Se}$ and CZTSe. Figure 3 shows the EDS results of the product powders prepared at $200^{\circ} \mathrm{C}$ for $45 \mathrm{~h}$ and $90 \mathrm{~h}$; it can be seen that the products also consist of four elements of $\mathrm{Cu}, \mathrm{Zn}, \mathrm{Sn}$, and Se. By comparing carefully the standard XRD pdf cards in Figure 2, it can be found that the strength ratios of $\mathrm{Cu}_{2} \mathrm{Se}$ and CZTSe have difference for three strong characteristic XRD peaks. In three strong peaks of standard XRD pdf cards of $\mathrm{Cu}_{2} \mathrm{Se}$, the strength ratio of the second strong peak for (220) or the third strong peak (311) with the first strong peak for (111) is relatively small, while those of CZTSe are relatively greater. From the XRD results of the CZTSe and $\mathrm{Cu}_{2} \mathrm{Se}$ powders prepared by authors, it is clearly seen that their strength ratios are different, which are similar to the difference for their standard XRD pdf cards. Figure 1 shows the strength ratios of the three strong peaks are similar to those of standard XRD pdf card of CZTSe. Combined the composition results by EDS, it can be considered that the product powders in this word are CZTSe powders.

3.3. The Morphology of $\mathrm{Cu}_{2} \mathrm{ZnSnSe}{ }_{4}$ Powders. The morphologies of samples prepared under the conditions of $180^{\circ} \mathrm{C}$ for $45 \mathrm{~h}$ (Figures $4(\mathrm{a})$ and $4(\mathrm{~b})$ ), $200^{\circ} \mathrm{C}$ for $45 \mathrm{~h}$ (Figures $4(\mathrm{c})$ and $4(\mathrm{~d})$ ), and $200^{\circ} \mathrm{C}$ for $90 \mathrm{~h}$ (Figures $4(\mathrm{e})$ and $4(\mathrm{f})$ ) were observed. It demonstrates that the microstructures of $\mathrm{Cu}_{2} \mathrm{ZnSnSe}_{4}$ nanopowders synthesized by chemical coreduction show flakes; the shape and size of the nanosheets also vary with the reaction condition changing. From Figures 4(a) and 4(b) it can be seen that the sample shows irregular polygons with about 30 40 $\mathrm{nm}$ sheet thickness and approximately $150 \sim 200 \mathrm{~nm}$ diameters. Figures 4(c) and 4(d) indicate that the nanosheets are approximately circular with about 30 40 nm sheet thickness and 150 200 nm diameters. From Figures 4(e) and 4(f) it can be seen that many small particles with different sizes exist in the sample prepared by reacting 


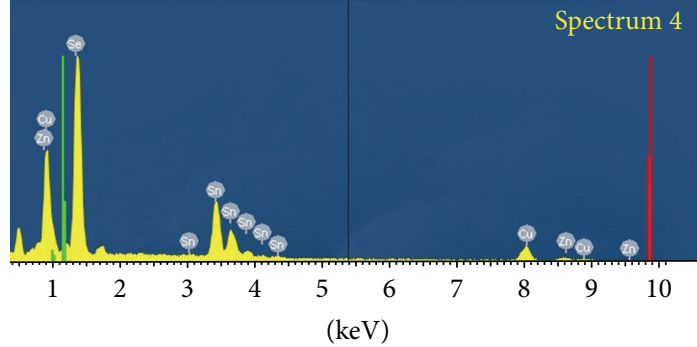

Full scale 2624 cts cursor: 5.404 (23cts)

(a)

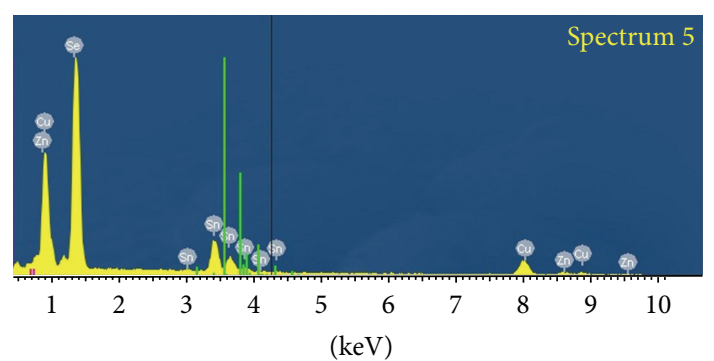

Full scale 3274 cts cursor: 4.291 ( $43 \mathrm{cts}$ )

(b)

Figure 3: The EDS results of $\mathrm{Cu}_{2} \mathrm{ZnSnSe}_{4}$ powders prepared at $200^{\circ} \mathrm{C}$ for different time. (a) $200^{\circ} \mathrm{C}$ for $45 \mathrm{~h}$, (b) $200^{\circ} \mathrm{C}$ for $90 \mathrm{~h}$.

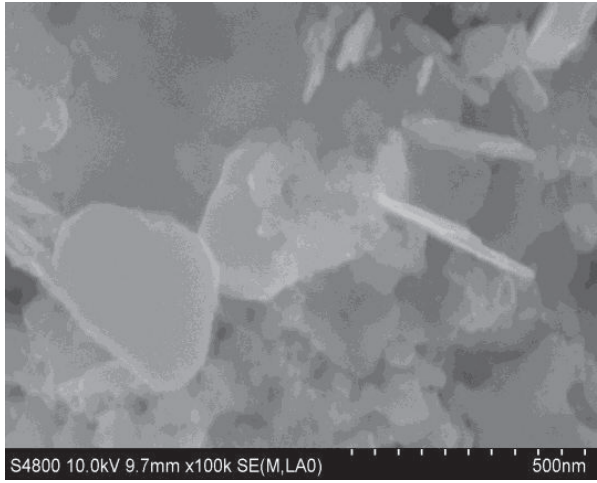

(a)

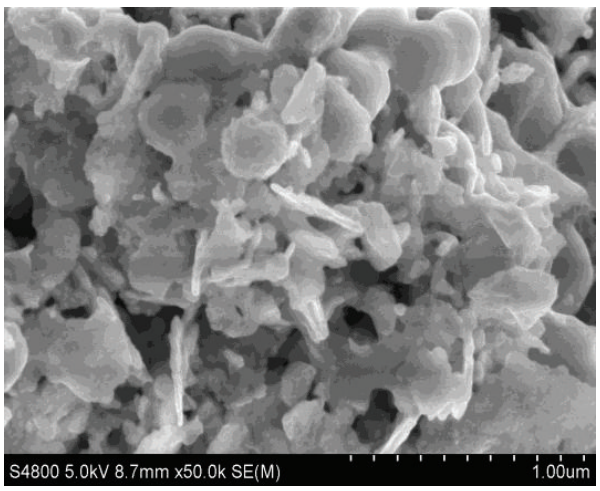

(c)

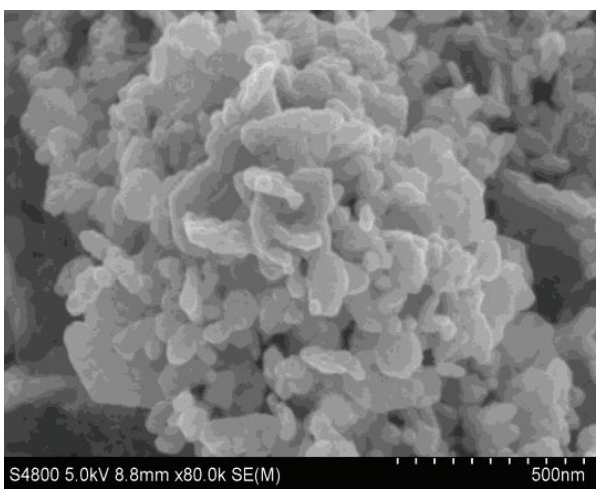

(e)

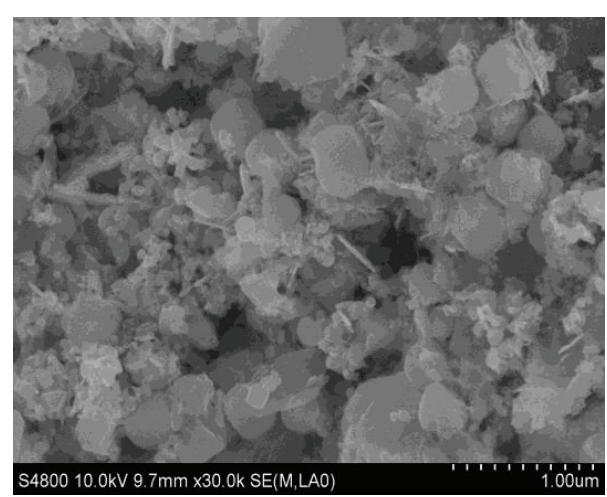

(b)

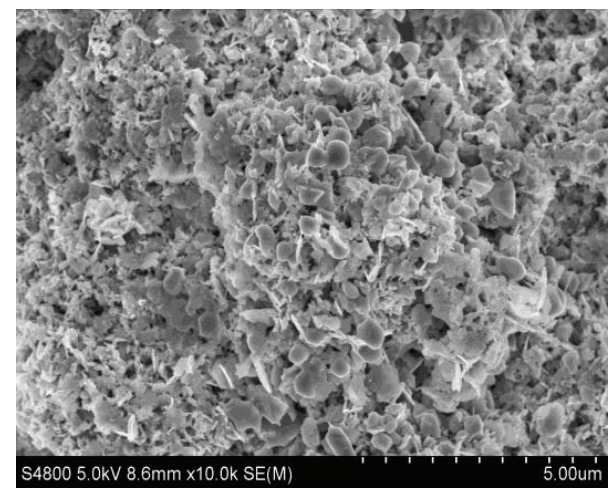

(d)

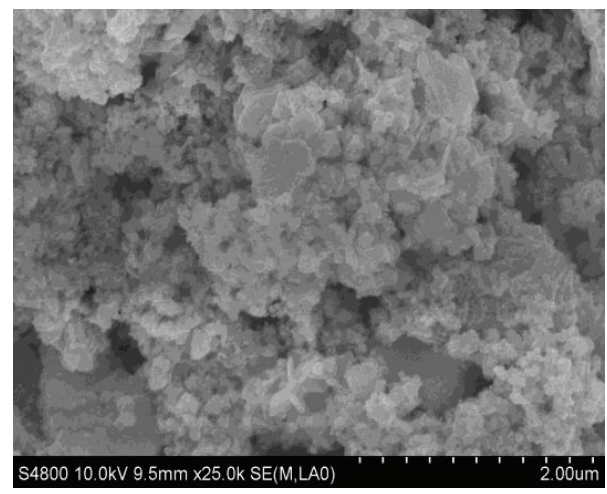

(f)

FIGURE 4: FESEM images of CZTSe powders synthesized under different conditions. (a) and (b): $180^{\circ} \mathrm{C}$ for $45 \mathrm{~h}$; (c) and (d): $200^{\circ} \mathrm{C}$ for $45 \mathrm{~h}$; (e) and (f): $200^{\circ} \mathrm{C}$ for $90 \mathrm{~h}$. 
at $200^{\circ} \mathrm{C}$ for $90 \mathrm{~h}$. It shows clearly more regular hexagonal flakes with $30 \sim 40 \mathrm{~nm}$ thickness under high magnification, which are similar to the nanoparticle of CZTSe prepared by Du et al. in shape while smaller than the latter in diameters of 50 70 nm [12].

\section{Conclusions}

The CTZSe powders were synthesized by hydrothermal coreduction method from metal chlorides and $\mathrm{SeO}_{2}$ with hydrazine hydrate as reducing agent at $160 \sim 200^{\circ} \mathrm{C}$. It indicates that well crystallized $\mathrm{Cu}_{2} \mathrm{ZnSnSe}_{4}$ powders can be obtained by reacting at $200^{\circ} \mathrm{C}$ for $90 \mathrm{~h}$. It provides a simple and easy-to-handle way to produce low-price and ecofriendly $\mathrm{Cu}_{2} \mathrm{ZnSnSe}_{4}$ powders. The CTZSe powders grow mainly along (112), (204), and (312) crystal planes, respectively. The FESEM results showed that the nanoparticles obtained are flaky with about 30 40 nm thickness and 50 $200 \mathrm{~nm}$ diameters.

\section{Conflict of Interests}

The authors declare that there is no conflict of interests regarding the publication of this paper.

\section{Acknowledgments}

This work was financially supported by the National Natural Science Foundation of China (nos. 51272140 and 51101093) and the Project of Shandong Province Higher Educational Science and Technology Program (no. J11LD10).

\section{References}

[1] P. Jackson, D. Hariskos, E. Lotter et al., "New world record efficiency for $\mathrm{Cu}(\mathrm{In}, \mathrm{Ga}) \mathrm{Se}_{2}$ thin-film solar cells beyond 20\%," Progress in Photovoltaics: Research and Applications, vol. 19, pp. 894-897, 2011.

[2] T. Rath, W. Haas, A. Pein et al., "Synthesis and characterization of copper zinc tin chalcogenide nanoparticles: influence of reactants on the chemical composition," Solar Energy Materials and Solar Cells, vol. 101, pp. 87-94, 2012.

[3] T. Teodor, G. Oki, and C. S. Jay, "Progress towards marketable earth-abundant chalcogenide solar cells," Thin Solid Films, vol. 519, pp. 10-13, 2011.

[4] S. Bag, O. Gunawan, T. Gokmen, Y. Zhu, T. K. Todorov, and D. B. Mitzi, "Low band gap liquid-processed CZTSe solar cell with 10.1\% efficiency," Energy and Environmental Science, vol. 5, no. 5, pp. 7060-7065, 2012.

[5] D. Park, D. Nam, S. Jung et al., "Optical characterization of $\mathrm{Cu}_{2} \mathrm{ZnSnSe}_{4}$ grown by thermal co-evaporation," Thin Solid Films, vol. 519, no. 21, pp. 7386-7389, 2011.

[6] P. M. P. Salomé, P. A. Fernandes, and A. F. da Cunha, "Morphological and structural characterization of $\mathrm{Cu}_{2} \mathrm{ZnSnSe}_{4}$ thin films grown by selenization of elemental precursor layers," Thin Solid Films, vol. 517, no. 7, pp. 2531-2534, 2009.

[7] Z. S. Chen, L. Han, L. Wan, C. Zhang, H. Niu, and J. $\mathrm{Xu},{ }^{\mathrm{C}} \mathrm{Cu}_{2} \mathrm{ZnSnSe}_{4}$ thin films prepared by selenization of coelectroplated Cu-Zn-Sn precursors," Applied Surface Science, vol. 257 , no. 20 , pp. 8490-8492, 2011.
[8] O. Volobujeva, S. Bereznev, J. Raudoja, K. Otto, M. Pilvet, and E. Mellikov, "Synthesis and characterisation of $\mathrm{Cu}_{2} \mathrm{ZnSnSe}_{4}$ thin films prepared via a vacuum evaporation-based route," Thin Solid Films, vol. 535, no. 1, pp. 48-51, 2013.

[9] D.-H. Kuo and J.-P. Hsu, "Property characterizations of $\mathrm{Cu}_{2} \mathrm{ZnSnSe}_{4}$ and $\mathrm{Cu}_{2} \mathrm{ZnSn}(\mathrm{S}, \mathrm{Se})_{4}$ films prepared by sputtering with single $\mathrm{Cu}-\mathrm{Zn}$-Sn target and a subsequent selenization or sulfo-selenization procedure," Surface and Coatings Technology, vol. 236, pp. 166-171, 2013.

[10] A. Shavel, J. Arbiol, and A. Cabot, "Synthesis of quaternary chalcogenide nanocrystals: stannite $\mathrm{Cu}_{2} \mathrm{Zn}_{x} \mathrm{SnySe}_{1+x+2 y}$," Journal of the American Chemical Society, vol. 132, no. 13, pp. 45144515, 2010.

[11] W. N. Liu, M. Q. Wu, L. D. Yan et al., "Noninjection synthesis and characterization of $\mathrm{Cu}_{2} \mathrm{ZnSnSe}_{4}$ nanocrystals in triethanolamine reaction media," Materials Letters, vol. 65, no. 17-18, pp. 2554-2557, 2011.

[12] Y.-F. Du, W.-H. Zhou, Y.-L. Zhou et al., "Solvothermal synthesis and characterization of quaternary $\mathrm{Cu}_{2} \mathrm{ZnSnSe}_{4}$ particles," Materials Science in Semiconductor Processing, vol. 15, no. 2, pp. 214-217, 2012.

[13] P. Y. Lee, S. C. Shei, and S. J. Chang, "Evolution pathways for the formation of Nano- $\mathrm{Cu}_{2} \mathrm{ZnSnSe}_{4}$ absorber materials via elemental sources and isophorondiamine chelation," Journal of Alloys and Compounds, vol. 574, pp. 27-32, 2013.

[14] H. Weia, Y. Sunb, Z. Yanga, and Y. Zhanga, "Hot-injection synthesis and characterization of quaternary $\mathrm{Cu}_{2} \mathrm{ZnSnSe}_{4}$ nanocrystals," Materials Letters, vol. 64, no. 13, pp. 1424-1426, 2010.

[15] K. Liu, H. Liu, J. Wang, and L. Shi, "Synthesis and characterization of $\mathrm{Cu}_{2}$ Se prepared by hydrothermal co-reduction," Journal of Alloys and Compounds, vol. 484, no. 1-2, pp. 674-676, 2009. 

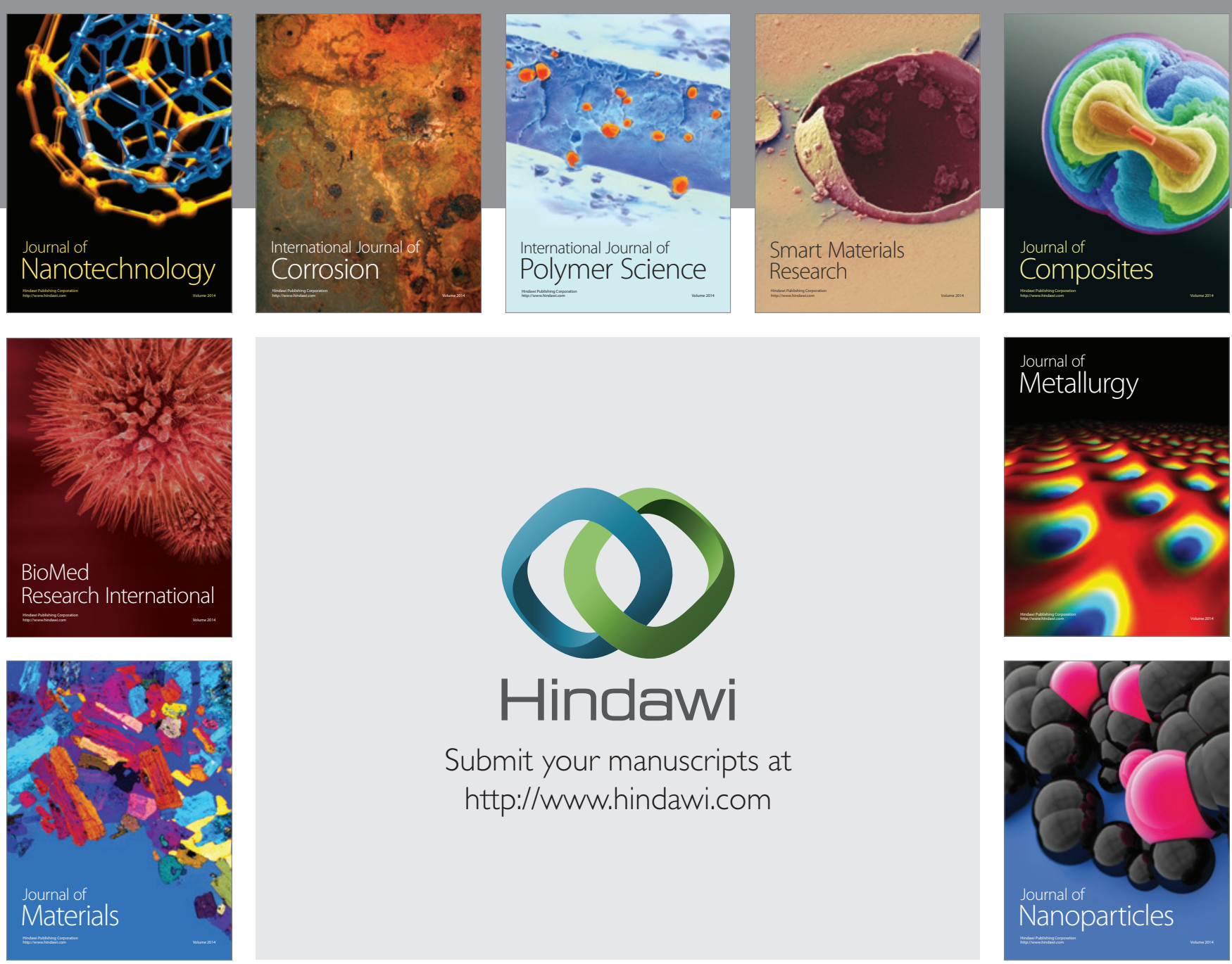

Submit your manuscripts at http://www.hindawi.com
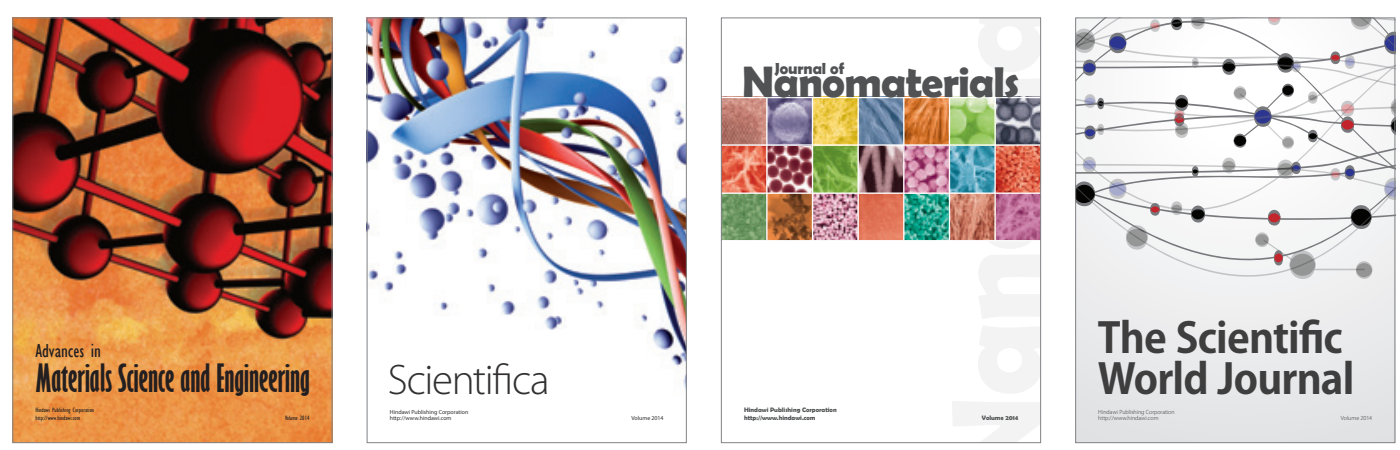

\section{The Scientific World Journal}
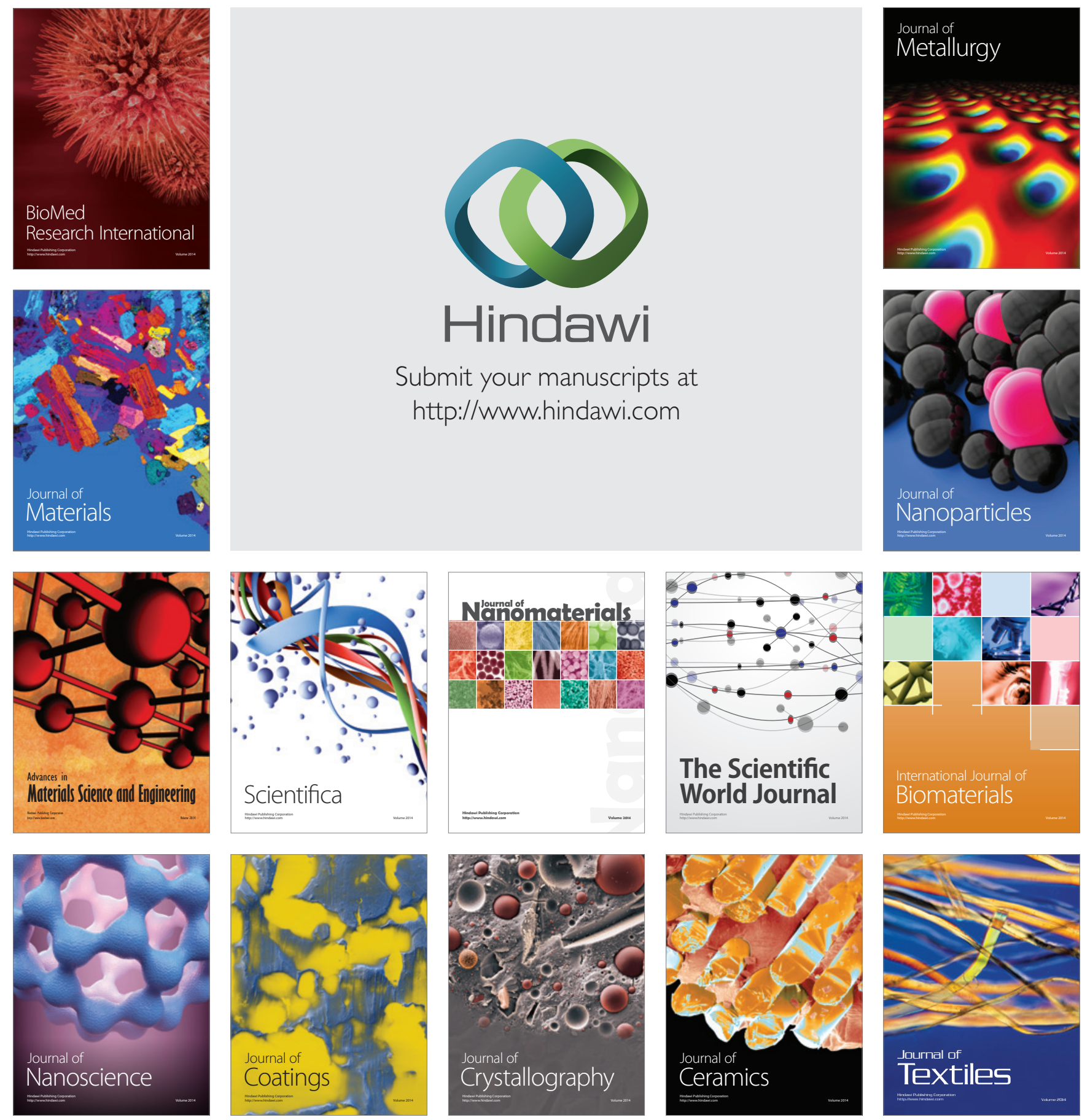